\title{
Pendidikan Karakter dalam Persepektif Pemikiran KH. Hasyim Asy'ari dan Thomas Lickona
}

\author{
${ }^{1}$ Muhammad Amrillah, ${ }^{2}$ Agus Khairul Assauqi \\ ${ }^{1}$ IAI Pangeran Diponegoro Nganjuk, ${ }^{2}$ IAI Pangeran Diponegoro Nganjuk \\ 1amrillah084@gmail.com, 2agusassauqi@iaipd-nganjuk.ac.id
}

\begin{abstract}
ABSTRAK
Latar belakang masalah dari penelitian ini adalah banyaknya fenomena yang mencerminkan kebobrokanbangsa seperti kekerasan, pemerkosaan dan masih banyak lainnya. Penelitian ini merupakan penelitian kualitatif dengan jenis penelitian kepustakaan (library research) dengan metode analisis (Content Analysis) setelah data terkumpul data dianalisa kemudian data tersebut dianalisa dan dipelajari secara cermat dan dideskripsikan yang selanjutnya memberikan gambaran dan penjelasan serta diuraikan persamaan dan perbedaan keduanya karna tujuan penelitian ini adalah mengetahui dan membandingkan pemikiran pendidikan karakter menurut Hasyim Asy'ari dan Thomas Lickona.

Hasil penelitian ini menunjukkan terdapat persamaan dan perbedaan diantara tokoh keduanya yang mana pemikiran HasyimAsy'ari mengenai pendidikan karakter lebih menekankan karakter terhadap subyek dan obyek pendidikan sedangkan pemikiran Thomas Lickona lebih condong kepadahal apa yang harus dilakukan oleh semua pihak sekolah, orang tua dan masyarakat untuk menanamkan pendidikan karakter.
\end{abstract}

\section{Kata Kunci: Pendidikan Karakter, HasyimAsy’ari dan Thomas Lickona}

\section{ABSTRACT}

The background problem of this research is the many phenomena that reflect the depravity of the nation such as violence, rape and many others. This research is a qualitative research with the type of library research (library research) with the method of analysis (Content Analysis) after the data is collected the data is analyzed then the data is analyzed and studied carefully and described which then provides an overview and explanation and describes the similarities and differences between the two because of the research objectives. this is knowing and comparing the thoughts of character education according to Hasyim Asy'ari and Thomas Lickona.

The results of this study indicate that there are similarities and differences between the two figures in which HasyimAsy'ari's thoughts on character education emphasize character towards the subject and object of education, while Thomas Lickona's thinking is more inclined towards what all schools, parents and society should do to instill character building.

\section{Keywords: Character Education, HasyimAsy'ari and Thomas Lickona}




\section{PENDAHULUAN}

Karakter adalah kecenderungan hati (sikap, attiude) dalam mereaksi sesuatu serta bentuk perilakunya (behavior). Dalam bahasa agama, karakter itu pada hakikatnya adalah akhlak, karakter yang baik disebut akhlak al-karimah, sedangkan karakter yang buruk disebut Akhlak al-Madhmumah. ${ }^{1}$

Masalah karakter merupakan masalah yang paling urgen dalam kehidupan manusia oleh karena itu akhir-akhir ini orang semakin menyadari betapa pentingnya pendidikan karakter di tengah-tengah kebobrokandan kebangkrutan moral bangsa, maraknya tindak kekerasan, inkoherensi politisi atas retorika politik dan perilaku keseharian yang tanpa kepedulian sesama, pendidikan karakter yang menekankan dimensi etis religius menjadi relevan untuk diterapkan, ${ }^{2}$ mereka mengatakan kecerdasan intelektual tanpa diikuti oleh karakter atau akhlak mulia maka tidak ada gunanya, ${ }^{3}$ dengan demikian semakin tinggi pendidikan seseorang harus semakin baik akhlaknya. Baik akhlak terahadap diri sendiri, lingkungan maupun dengan sang Khalik. Sehingga seseorang akan terhindar dari istilah "pinter keblinger". Istilah ini digunakan masyarakat menilai pejabat-pejabat Negara kitayang rata-rata berpendidikan tinggi tapi masih saja melakukan korupsi, kolusi dan nepotisme,padahal mereka semuanya mengetahui apa hukum melakukan tindakan tercela itu, dalam bahasa pesantren hal seperti itu disebut ilmu yang tidak bermanfaat yang membawa madarat bagi oran lain.

Pendidikan karakter menjelma menjadi isu nasional ketika anak bangsa mulai banyak yang menunjukkan tanda-tanda degradasi kualitas karakter. Pendidikan karakter digadang-gadang menjadi pendekar yang akan menyelesaikan salah satu program akut yang mendera bangsa ini.

Bangsa yang besar adalah bangsa yang memiliki karakter yang mampu membangun sebuah peradaban yang besar yang kemudian mempengaruhi perkembangan dunia. ${ }^{4}$ Tercatat dalam sebuah sejarah Nabi Muhammad SAW., sebagai manusia sempurna yang hidup dimuka bumi ini telah memberikan contoh keteladanan bagaimana membangun karakter suatu bangsa dan mempengaruhi dunia.

Terkait dengan pendidikan karakter ini, Hasyim Asy'ari pendiri Nahdlatul 'Ulama' turut andil mengkonsepkan pendidikan karakter khas pesantren yang dalam kitabnya Adab al-'Alim waal Muta'allim yang membahas tentang keutamaan ilmu ulama,' belajar-mengajar, karakter pelajar terhadap diri sendiri, karakter pelajar

\footnotetext{
${ }^{1}$ Asep Zaenal, Islamic Characther Building (Jakarta: PT Grafindo Media Pratama, 2014), 2.

${ }^{2}$ Larry P. Puccy dan Narcia Narvaes HandBook Pendidikan Moral dan Karakter:, (Terj) Imam Baihaqi dan Derta Sri Widowati (Bandung: Nusa Media Ujung Berung, 2014), 131.

${ }^{3}$ Imam Suprayogo, Menghidupkan Jiwa Ilmu( kumpulan Kolom Seputar Pendidikan) (Jakarta: PT Elex Media Komputindo, 2014), 22.

${ }^{4}$ Akh. Muwafik Sholeh, Membangun Karakter Dengan Hati Nurani ( Jakarta: Erlangga, 2012), 1.
} 
terhadap pendidik, karakter pelajar terhadap pelajaran, karakter orang berilmu pada diri sendiri, karakter pendidik dalam belajar mengajar, karakter pendidik terhadap pelajar, dan karakter terhadap buku pelajaran. ${ }^{5}$

Sementara itu menurut Thomas Lickona,seorang ahli psikologi perkembangan dan seorang professor pendidikan di State University of New York, membahas pendidikankarakter dalam bukunya ' Educating for Character' yang memuat uraian rinci dan contoh-contoh apa yang harus dilakukan oleh gurudan sekolah untuk menanamkan ke dalam jiwa siswa tujuh nilai universal dan nonkonteroversial:jujur,adil,tanggung jawab, berani, mau bekerja dan disiplin. Di tengah merosotnya moralitas dan maraknya tawuran pelajar di lingkungan sekolah. ${ }^{6}$

Melihat dari pendapat kedua para tokoh terdapat perbedaan dan persamaan mengenai pendidikan karakter.Terlebih kedua tokoh tersebut berbeda latar belakang, Hasyim Asy'ari seorang 'ulama' salaf sedangkan Thomas Lickona pakar Pendidikan Amerika yang beragama Katolik, tentunya disini penulis lebih tertarik untuk mengkajinya.

\section{A. Ruang Lingkup Penelitian}

Untuk memperoleh data yang relevan dan memberikan arah pembahasan pada tujuan yang telah dirumuskan, maka ruang lingkup penelitian inidifokuskan pada sekitarpendidikan karakter, khususnya pemikiranHasyim Asy'ari di dalam kitabnya Adab al-'Alim wa-al Muta'allim dan pemikiran Thomas Lickona dalam bukunya Educating For Character yang meliputi konsep pendidikan karakter menurut Hasyim Asy'ari, konsep pendidikan karakter menurut Thomas Lickona serta Persamaan dan perbedaan pendidikan karakter menurut Hasyim Asy'ari dan Thomas Lickona. Adapun dalam pembahasan apabila ada permasalahan diluar tersebut di atas, maka sifatnya hanyalah penyempurna sehingga pembahasan ini sampai pada sasaran yang dituju.

\section{KAJIAN TEORI}

\section{A. Pengertian Karakter}

Secara harfiah, karakter artinya kualitas mental atau moral. Dalam kamus psikologi, karakter adalah kepribadian yang ditinjau dari titik tolak etis atau moral, misalnya kejujuran seseorang yang biasanya mempunyai kaitan dengan sifat-sifat yang relatif tetap. ${ }^{7}$ Menurut Shimon Philip dalam buku Refleksi Karakter Bangsa, karakter adalah kumpulan tata nilai yang menuju

\footnotetext{
${ }^{5}$ Hasyim Asy'ari, Pendidikan Karakter Khas Pesantren:, (Terj.)Rosidin (Malang: GENIUS, 2014),Sampul Buku.

${ }^{6}$ Thomas Lickona Pendidikan Karakter Panduan Lengkap Mendidik Siswa Menjadi Pintar dan Baik:, (Terj.) Lita S (Bandung: Nusa Media, 2013), Sampul Buku. ${ }^{7}$ Barnawi, M. Arifin, Strategi dan Kebijakan Pembelajaran Pendidikan Karakter ( Jogjakarta: Ar-Ruuz Media, 2012), 20.
} 
pada suatu sistem, yang melandasi pemikiran, sikap, dan perilaku yang ditampilkan. $^{8}$

Menurut Ensiklopedia Indonesia bahwa karakter/watak adalah keseluruhan aspek perasaan dan kemauan menampak keluar sebagai kebiasaan, pada cara bereaksi terhadap dunia luar, dan pada yang di idam-idamkannya. ${ }^{9}$

Berdasarkan pendapat mengenai hakikat karakter dapat disimpulkan bahwa karakter itu berkaitan dengan konotasi positif, bukan netral jadi orang yang berkarakter adalah orang yang mempunyai kualitas moral (tertentu) positif yang menyangkut perilaku terpuji dan baik. Karakter seseorang yang positif atau yang mulia menjadikan derajat seseorang semakin tinggi bagi dirinya. Individu yang berkarakter baik atau unggul merupakan seseorang yang berusaha melakukan hal-hal yang terbaik terhadap Tuhan Yang Maha Esa, dirinya serta lingkungan. Dalam Islam seseorang yang berkarakter unggul adalah orang yang bertakwa kepada Allah SWT. Yang menjauhi segala larangan Nya dan menaati semua perintahNya.

\section{B. PengertianPendidikan Karakter}

Secara denitif, pendidikan (pedagogik) menurut Jhon Dewey Pendidikan adalah proses pembentukan kecakapan kecakapan fenomental secara intelektual dan emosional kearah alam dan sesama manusia. ${ }^{10}$

Menurut Ki Hajar Dewantara, mendidik adalah menuntun segala kekuatan yang ada pada anak-anak agar mereka sebagai anggota masyarakat dapat mencapai keselamatan dan kebahagiaan setinggi tingginya dalam rangka memerdekakan aspek lahiriah dan bathiniah manusia. ${ }^{11}$

Menurut Al-Ghozali pendidikan adalah proses memanusiakan manusia sejak masa kejadiannya sampai akhir hayatnya melalui berbagai ilmu pengetahuan yang disampaikan dalam bentuk pengajaran secara bertahap dimana proses pengajaran itu menjadi tanggung jawab orang tua dan masyarakat menuju pendekatan diri kepada Allah sehingga menjadi manusia sempurna. ${ }^{12}$ Di Indonesia, pendidikan karakter harus diterapkan sejak usia dini, yaitu jenjang pendidikan sebelum jenjang pendidikan dasar yang merupakan upaya pembinan yang ditujukan bagi anak sejak lahir sampai dengan usia enam tahun yang dilakukan melalui pemberian rangsangan pendidikan untuk membantu pertumbuhan dan perkembangan jasmani dan rohani agar anak

${ }^{8}$ Masnur Muslih,Pendidikan Karakter: Menjawab Tantangan Krisis

Multidimensional (Jakarta: PT Bumi Aksara, ), 70.

${ }^{9}$ Ramayulis, Ilmu Pendidikan Islam (Jakarta: Kalam Mulia, 2012), 510.

${ }^{10}$ Abu Ahmadi, Nur Uhbiadi, Ilmu Pendidikan (Jakarta: PT. Rineka Cipta, 2001), 110.

${ }^{11}$ Bartolomeus Samho, Visi Misi Pendidikan Ki Hajar Dewantara Tantangan dan

Relevansinya (Yogyakarta: Kanisius (Anggota Ikapi, 2013), 74.

${ }^{12}$ Abidin Ibnu Rusd, Pemikiran Al-Ghazali tentang Pendidikan(Yogyakarta:PustakaPelajar), 56. 
memiliki kesiapan memasuki pendidkan lebih lanjut yang diselenggarakan baik lembaga formal, nonformal dan informal. ${ }^{13}$

Sedangkan arti dari pendidikan karakter itu sendiri adalah upaya-upaya yang dirancang dan dilaksanakan secara sistematis untuk membantu peserta didik memahami nilai-nilai perilaku didik perilaku manusia yang berhubungandengan Tuhan Yang Maha Esa, diri sendiri, sesama manusia, lingkungan dan kebangsaan. ${ }^{14}$ Menurut David Elkind \& Freddy Sweet (2004), Characther Education is the deliberate effort to help people understan, care about, and act upon core ethical value (Pendidikan karakter adalah usaha sengaja (sadar) untuk membantu manusia memahami, peduli tentang, dan melaksanakan nilai-nilai etika inti). ${ }^{15}$

Menurut Burke pendidikan karakter adalah semata-mata merupakan bagian dari pembelajaran yang baik dan merupakan bagian yang fundamental dari pendidikan yang baik. ${ }^{16}$ Dalam pengertian yang sederhana pendidikan karakter adalah hal positif apa saja yang dilakukan guru dan berpengaruh kepada siswa yang diajarnya, pendidikan karakter adalah upaya sadar dan sungguh-sungguh dari seorang guru untuk mengajarkan nilai kepada para siswanya. $^{17}$

Departemen Pendidikan Amerika Serikat mendefinisikan pendidikan karakter sebagai proses belajar yang memungkinkan siswa dan orang dewasa untuk memahami, peduli, dan bertindak pada nilai- nilai etika inti, seperti rasa hormat, keadilan, kebajikan, warga negara yang baik, dan bertanggung jawab. Jadi pada intinya pendidikan karakter adalah proses pemberian tuntunan kepada peserta didik untuk menjadi manusia seutuhnya yang berkarakter dalam dimensi hati, pikir, raga,serta rasa dan karsa.

\section{Faktor Pembentukan Karakter}

Karakter bukan bawaan melainkan dibentuk, dalam pendidikan Islam pembentukan karakter ialah suatu usaha sadar yang menimbulkan tindakantindakan perbuatan yang konsisten dan sesuai dangan nilai-nilai Islam. Karakter yang berkualitas perlu dibentuk dan dibina sejak dini. Usia dini merupakan masa kritis bagi pembentukan karakter seseorang. Pembentukan karakter dapat dibina melalui pendidikan formal yaitu, sekolah maupun informal yang dapat terjadi dilingkungan keluarga. Pada dasarnya setiap anak

\footnotetext{
${ }^{13}$ Anas salahudin, Filsafat Pendidikan (Bandung : Pustaka Setia, 2011), 205.

${ }^{14}$ Jamal Ma'mur Asmani, Buku Panduan Internalisasi Pendidikan Karakter Di Sekolah (Yogyakarta: Diva Press 2011), 35.

${ }^{15}$ Zubaedi, Desain Pendidikan Karakter Konsepsi dan Aplikasinya dalam Lembaga Pendidikan (Jakarta : Kencana, 2012),15.

${ }^{16}$ Maisah, Manajemen Pendidikan (Jakarta: Gaung Persada Press,2013), 35.

${ }^{17}$ Muchlas samani \& Hariyanto, Konsep dan Model Pendidikan Karakter, (Bandung: PT Remaja Rosda Karya, 2011), 43.
} 
yang lahir ke dunia dalam keadaan fitrah (suci) bahkan hanif (lurus) sesuai dengan firman Allah dalam surat Ar-Rum ayat 30 :

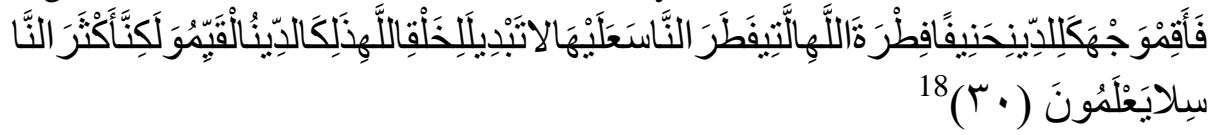

Artinya :' Hadapkanlah wajahmu dengan lurus kepada agama Allah yang telah menciptakan manusia menurut fitrahnya. Tidak ada perubahan bagi fitrah Allah, itulah agama yang lurus, tetapi kebanyakan manusia tidak mengetahui' '(QS. Ar-Rum: 30)

Berdasarkan Ayat di atas, maka ada faktor-faktor yang dapatmempengaruhi karakter seorang anak diantaranya :

1. Corak nilai yang ditanamkan

Seseorang bisa dicuci otaknya dan di ubah orientasi hidupnya dengan nilainilai baru yang didoktrinkan.

2. Keteladanan sang idola

Satu keteladanan lebih berpengaruh daripada seribu bahasa anak- anak lebih terpengaruh kepada idola mereka, maka perlu di arahkan agar anak lebih menyukai tokoh idola yang benar-benar menjadi tauladan seperti Rasullullah SAW. Dan sahabat-sahabatnya.

3. Pembiasaan

Merupakan kebiasaan yang dilakukan yang terus menerus akan menancap pada jiwa sang anakseperti membiasakan anak berperilaku terpuji.

4. Ganjaran dan hukuman

Hukuman bisa memaksa seseorang menaati peraturan ganjaran dapat memotivasi seseorang.

5. Kebutuhan

Kebutuhan dan perasaan tertekan akan bisa mengubah orientasi kehidupan seseorang.

\section{Desain Pendidikan Karakter}

Desain merupakan gambaran, kerangka bentuk, ${ }^{19}$ dalam membuat pola yang kita rencanakan, begitupun dalam mendesain sebuah pendidikan karakter jika ingin efektif dan utuh, pendidikan karakter mesti menyertakan tiga basis desain dalam pemogramannya. Tanpa tiga basis itu, program pendidikan karakter di sekolah hanya wacana semata.

1. Desain pendidikan karakter berbasis kelas

Desain ini bertumpu pada relasi guru sebagai pendidik dan siswa sebagai pembelajar di dalam kelas yang melakukan interaksi. Interaksi yang

18 Al-Qur-an, 30 (Ar-Rum) : 30.

${ }^{19}$ Departemen Pendidikan Nasional Kamus Besar Bahasa Indonesia(Jakarta: Balai Pustaka, 2001), 257. 


\section{$J$ Kis

kita maksud disini tidak terlepas dari komunikasi, yang banyak melibatkan komponen komunikator, komunikan, pesan dan media. ${ }^{20}$ Guru, dalam proses pembelajaran, mampu menempatkan diri sebagai pribadi di tengahtengah kehidupan pribadi peserta didik yang sedang dalam proses optimalisasi potensi, sehingga mampu memahami apa yang menjadi kebutuhan, motivasi, kelemahan dll. ${ }^{21}$ Termasuk juga guru membantu dalam manajemen kelas, konsensus kelas sehingga membantu terciptanya suasana belajar yang nyaman.

2. Desain pendidikan karakter berbasis kultur sekolah

Desain ini mencoba membangun kultur sekolahyang mampu membentuk karakter anak didik. Guna menciptakan kultur sekolah yang bermoral perlu diciptakan lingkungan sekolah yang dapat mendorong murid-murid memiliki moralitas yang baik/karakter yang terpuji, ${ }^{22}$ sebagai contoh sekolah yang memiliki iklim demokratis, murid-murid akan terdorong bertindak demokratis, sebaliknya jika suatu sekolah terbiasa mempraktekkan tindakan-tindakan otoriter maka sulit untuk mendidik mereka menjadi pribadi yang demokratis.

3. Desain pendidikan karakter berbasis komunitas.

Sekolah tidak berjuang sendirian dalam mendidik siswa. Masyarakat di luar lembaga pendidikan juga turut berperan penting, seperti keluarga merupakan lingkungan sekaligus, sarana pendidikan nonformal yang paling dekat dengan anak keluarga merupakan unit terkecil masyarakat yang terbentuk melalui perkawinan yang sah baik menurut hukum sayariat Islam maupun perundang-undangan Negara. ${ }^{23}$ Kontribusinya terhadap keberhasilan anak didik cukup besar. ${ }^{24}$ Begitupun juga dengan lingkungan sekitar atau masyarakat sangat berpengaruh sekali dalam menanamkan nilai-nilai karakter terhadap peserta didik, masyarakat umum dan negara turut bertanggung jawab untuk mengintegrasikan pembentukan karakter dalam kehidupan mereka.

\section{E. Dasar Hukum Pendidikan Karakter}

Berikut ini adalah dasar hukum pembinaan pendidikan karakter

1. Undang-Undang Dasar 1945.

2. Undang-Undang Nomer 20 Tahun 2003 Tentang Sistem Pendidikan Nasional.

\footnotetext{
${ }^{20}$ Martinis Yamin, Kiat Membelajarkan Siswa ( Jakarta: Gaung Persada Press, 2007), 239.

${ }^{21}$ Nyoman surna, Olga D. Pandeirot, Psikologi Pendidikan(Jakarta: Erlangga, 2014), 154.

${ }^{22}$ Damiyati Zuhdi dkk, Model Pendidikan Karakter (Yogyakarta: Pustaka Pelajar, 2013), 42.

${ }^{23}$ Imam Suprayoga, Quo Hadist pendidikan Islam pembacaan Realitas pendidikan Islam, Sosial dan keagamaan( Malang: UIN Malang Press, 2006). 154.

${ }^{24}$ Agus Wibowo, Pendidikan Karakter Strategi Membangun Karakter Bangsa dan Peradaban(Yogyakarta:Pustaka Belajar, 2012), 105.
} 
3. Peraturan Pemerintah Nomer 19 Tahun 2005 tentang Standar Pendidikan Nasional.

4. Permendiknas No 39 Tahun 2008 tentang Pembinaan Kesiswaan.

5. Permendiknas Nomor 22 Tahun 2006 tentang Standar Isi.

6. Permendiknas Nomor 23 Tahun 2006 tentang Standar Kompetensi Kelulusan.

7. Rencana pemerintah Jangka Menengah Nasional 2010-2014.

8. Renstra Kemendiknas Tahun 2010-2014.

9. Renstra Direktorat pembinaan SMP tahun 2010-2014.

\section{F. Metodologi Pendidikan Karakter.}

Pendidikan karakter jelas membutuhkan metodologi yang efektif, aplikatif, dan produktif agar tujuannya bisa tercapai dengan baik. Menurut Doni Koesoema, metodologi pendidikan karakter adalah sebagai berikut:

\section{Pengajaran}

Mengajarkan Pendidikan Karakter dalam rangka memperkenalkan pengetahuan teoritis tentang konsep-konsep nilai. Pemahaman konsep ini menjadi bagian dari pemahaman pendidikan karakter itu sendiri. Sebab, peserta didik akan banyak belajar dari pemahaman dan pengertian tentang nilai-nilai yang dipahami oleh para guru dalam setiap pertemuan mereka.

2. Keteladanan

Keteladanan merupakan salah satu metode klasik bagi berhasilnya sebuah tujuan pendidikan karakter. Selain seorang guru harus mempunyai kompetensi dalam mengajar tapi guru harus bisa menjadi tauladan yang baik bagi peserta didiknya baik dalam kehidupan di dalam maupun diluar sekolah.

3. Menentukan Prioritas

Lembaga Pendidikan perlu memiliki prioritas dan tuntutan dasar atas karakter yang ingin diterapkan di lingkungan mereka. Pendidikan karakter harus menentukan tuntutan standar atas karakter yang akan ditawarkan kepada peserta didik sebagai bagian dari kinerja kelembagaan mereka.

4. Praksis Prioritas

Melaksanakan prioritas adalah unsur lain yang sangat penting bagi pendidikan karakter dan sebagai bukti dari rencana yang telah dilakukan oleh lembaga pendidikan. Berkaitan dengan tuntutan lembaga pendidikan harus mampu membuat verifikasi sejauh mana visi sekolah dapat direalisasikan dalam lingkup pendidikan skolastik melalui berbagai macam unsur yang ada di dalam lembaga itu sendiri.

5. Refleksi 


\section{JKÍs

Karakter yang ingin dibentuk oleh lembaga pendidikan melalui berbagai macam program dan kebijakan perlu dilakukan evaluasi dan direfleksikan secara berkesinambungan dan kritis. Tanpa ada usaha untuk melihat kembali sejauh mana proses pendidikan karakter ini direfleksikan dan dievaluasi, tidak akan pernah terdapat kemajuan.

\section{METODE PENELITIAN}

Desain atau rancangan penelitian pada dasarnya merupakan keseluruhan proses pemikiran dan penentuan matang tentang hal-hal yang akan dilakukan. Ia merupakan landasan berpijak, serta dapat pula dijadikan dasar penilaian baik peneliti itu sendiri maupun orang lain terhadap kegiatan penelitian. ${ }^{25}$

Penelitian ini menggunakan metode kualitatif, yaitu metode penelitian yang menghasilkan penemuan-penemuan yang tidak dapat dicapai dengan menggunakan prosedur-prosedur statistik atau dengan cara-cara lain dari kuantifikasi (pengukuran). ${ }^{26}$ Adapun ciri-ciri penelitian kualitatif menurut Prof. DR. Lexy J. Moleong adalah: latar alamiah, manusia sebagai alat (instrument), metode kualitatif, analisis data secara induktif, teori dasar(ground theory), adanya batas yang ditentukan oleh fokus, adanya kriteria khusus untuk keabsahan data, desain yang bersifat sementara, hasil penelitian dirundingkan dan di sepakati bersama. ${ }^{27}$

Penelitian ini menggunakan jenis penelitian kepustakaan (library research) yaitu penelitian dengan menelusuri literatur-literatur yang ada, serta menelaahnya secara tekun agar memperoleh ide tentang masalah yang up to date dengan menggali teori-teori yang berkembang dalam bidang ilmu pengetahuan. ${ }^{28}$

Sifat Penelitian ini adalah penelitian deskriptif yaitu penelitian yang dirancang untuk memperoleh informasi tentang status gejala saat penelitian dilakukan. Penelitian ini diarahkan untuk menetapkan sifat suatu situasi pada waktu penyelidikan itu dilakukan. Dalam penelitian deskriptif, tidak ada perlakuan yang diberikan atau dikendalikan seperti yang dapat ditemui dalam penelitian eksperimen. Tujuan penelitian ini adalah melukiskan variabel atau kondisi "apa yang ada" dalam situasi. ${ }^{29}$

Berdasarkan hal itu, maka penelitian ini hendak menguraikan secara lengkap, teratur dan teliti terhadap suatu obyek penelitian, yaitu menguraikan dan

\footnotetext{
${ }^{25}$ S. Margono, Metodologi penelitian pendidikan, ( Jakarta : PT Rineka Cipta, 2010),100.

${ }^{26}$ Anselm Strauss dan Juliet Corbin, Dasar- Dasar Penelitian Kualitatif (Surabaya: PT Bina Ilmu, 1997), 11.

${ }^{27}$ Lexy J. Moeloeng, Metodologi Penelitian Kualitatif, (Bandung: Remaja Rosda Karya, 2005), 4.

${ }^{28}$ Moh. Nazir,Metode Penelitian (Jakarta: Ghalia Indonesia, 1998), 51-52.

${ }^{29}$ Arif Furhan,Pengantar Penelitian dalam Pendidikan (Yogyakarta: Pustaka Pelajar, 2004), 447.
} 
menjelaskan persamaan dan perbedaan teori yang diuraikan Hasyim Asy'ari dan Thomas Lickona mengenai konsep pendidikan karakter.

\section{HASIL DAN PEMBAHASAN}

\section{Persamaan pemikiran pendidikan karakter menurut Hasyim Asy'ari dan Thomas Lickona.}

Setelah mengkaji dari pemikiran pendidikan karakter menurut Hasyim Asy'ari dan Thomas lickona, terdapat persamaan mengenai pemikiran pendidikan karakter menurut keduanya. Hasyim Asy'ari dan Thomas Lickona merupakan kedua tokoh yang sama-sama karya mereka banyak diterjemah dan dijadikan referensi mengenai pendidikan karakter. Sudah menjadi rahasia umum bahwa konsep yang ditawarkan Hasyim Asy'ari lewat pemikirannya yang dituangkan dalam karyanya yakni kitab Adab al-'Alim wa-al Muta'allim yang kini banyak diterjemahkan dalam bahasa Indonesia sebagai pendidikan karakter ala pesantren yang banyak dikaji di pesantren-pesantren dan masih dianggap relevan untuk diterapkan sebagi pedoman mendidik tunas bangsa menjadi karakter yang unggul. Begitu juga lewat pemikirannya Thomas Lickona tentang pendidikan karakter yang tertuang dalam bukunya Educating for Character yang banyak diterjemah di Negara-Negara lain termasuk Negara kita Indonesia yang banyak dikaji dikalangan cendikiawan yang membahas karakter dan merupakan pembaharuan konsep karakter di zaman yang global ini untuk mengentas kemerosotan moral.

Terkait dengan persamaan pemikiran pendidikan karakter menurut

keduanya yakni Hasyim Asy'ari dan Thomas Lickona. Keduanya sama-sama mensyaratkan seorang pendidik memiliki karakter terhadap peserta didiknya. Yang setelah dikaji ada tiga karakter yang harus dimiliki seorang guru menurut Hasyim Asy'ari dan Thomas Lickona yakni akan dijelaskan secara rinci di bawah ini.

1. Seorang guru harus mempunyai kasih sayang terhadap muridnya

Manusia adalah makhluk sosial, makhluk yang selalu membutuhkan orang lain dan makhluk yang membutuhkan ksaih sayang, kasih sayang bak pelita dalam hati yang mengisi rongga jiwa. Barang siapa ingin yang mencintai dirinya dan ingin dicintai orang lain maka ia harus menghidupkan perasan kasih sayang terhadap dirinya. Ketika seorang guru misalnya tidak mempunyai rasa kasih sayang dan tidak mencintai anak didiknya maka bagaimana mungkin ia dapat membimbing dan mengarahkannya untuk meraih tujuan pendidikan yang kita inginkan. Karena itu kasih sayang memiliki peran penting dalam dunia pendidikan dan merupakan salah satu metode pendekatan yang paling berpengaruh dan efektif dalam pendidikan sebab kasih sayang memiliki daya tarik dan memotivasi untuk menumbuhkan karakter yang baik tehadap peserta didik.

Terdapat dalam kitabnya Adab al-'Alim wa-al Muta'allim Hasyim Asy'ari menjelaskan seorang guru harus mempergauli pelajar dengan penuh 
kasih sayang, mencintai pelajar sebagaimana mencintai dirinya sendiri menganggapnya seolah-olah pelajar adalah anak kandungnya kemudian bertutur lemah lembut, tidak bersikap kasar, tidak pilih kasih dan berjiwa pema'af. Menurut hasyim Asy'ari sikap kasih sayang seorang pendidik tercermin pada perhatian seorang pendidik kepada pelajar, yang mana seorang pendidik sebaiknya memperhatikan keadaan pelajarnya, jika ia tidak masuk maka menanyakannya kepada orang yang dekat dengannya atau kerabatnya, apabila ia sakit maka hendaknya dijenguk, apabila dalam keadaan susah maka seorang pendidik yang baik akan membantunya sesuai dengan kemampuannya dan apabila pelajar mau bepergian maka sebaiknya diperhatiakn dengan siapa ia berangkat dan tujuannya apa setelah itu mengizininya dengan iringan doa.

Bukti dari sikap kasih sayang Hasyim asy'ari juga menuturkan yakni tercermin dari perilaku seorang pendidik yang mana seorang pendidik sebaiknya bertutur kata yang ramah kepada setiap muridnya apalagi kepada murid senior, memanggilnya dengan nama yang baik, tidak merendahkannya atau mempermalukannya dan pendidik sebaiknya tampil di depan pelajar, dengan mimik muka yang cerah tidak dengan keadaan emosi yang meledak ledak karena seorang guru yang baik adalah Guru yang penyayang memahami betul perannya kapan ia harus mendukung siswanya, menasihati, memarahi, dan memberikan suatu perilaku siswa.

Hal ini senada dengan Thomas Lickona yang terdapat di bagian dua di karangan bukunya yakni Educating For Character yang menjelaskan strategi mengajarkan sikap hormat dan tanggung jawab di kelas, yang didalamnya seorang guru harus menjadi seorang pengasuh, teladan, pembimbing, yang memperlakukan siswanya dengan hormat dan kasih sayang, tidak bersikap pilih kasih, karna menurut Thomas Lickona bentuk paling dasar dari pendidikan moral adalah perlakuan yang kita terima yang mana jika seorang pendidik memperlakukan siswanya dengan kasih sayang maka otomatis perilaku yang diterima siswa tersebut akan ditirunya dan mereka akan memperlakukan orang, hewan, dan bahkan dengan benda-benda yang mati dengan perlakuan kasih sayang kana pada dasarnya nak-anak senang jika diperlakukan dengan hangat dan kasih sayang karna kasih sayang adalah sumber kebahagian bagi mereka dan tidak berbicara kasar yang meremehkan dan mempermalukan siswa. Adapun pendidik sangat keras akan ditakuti oleh anak sikap pendidik sebaiknya harus senang terhadap anak didik dengan penuh rasa tnggung jawab dan penuh obtyektif serta bersikap ramah adil dan tanggung jawab untuk menuju kesejahteraan anak didik. ${ }^{30}$

2. Seorang guru harus membina hubungan baik dengan siswa

${ }^{30}$ Sutari Imam Barnadib, Pengantar Ilmu Pendidikan Sistematis, (Yogyakarta: Andi offset,1995), 63. 
Hubungan guru dengan siswa/anak didik di dalam proses belajar mengajar merupakan faktor yang sangat menentukan. bagaimanapun baiknya metode yang digunakan, bagaimanapun baik bahan yang diberikan, namun jika hubungan siswa tidak harmonis maka tidak akan mencapai suatu hasil yang di inginkan. ${ }^{31}$ Guru ideal yang di inginkan siswa adalah guru yang bisa menjalin hubungan baik dengan siswanya. Guru yang bisa menjalin hubungan baik dengan siswanya akan mengerti bagaimana menghadapi siswa-siswanya. Hasyim asy'ari mengatakan seorang pendidik yang baik merupakan pendidik yang bisa menjaga keharmonisan hubungan antar pelajar melalui menebar salam, tutur kata yang baik dalam pembicaraan, saling kasih mengasihi, saling tolong menolong dalam hal kebaikan. Hal ini sejajar dengan pemikiran Thomas Lickona bahwasanya seorang guru harus bisa membangun hubungan baik dengan siswanya. Dengan memiliki hubungan baik berarti memiliki hubungan personal yang hangat, saling mempercayai, dan selaras dengan para siswa sehingga mereka lebih mudah untuk membicarakan masalah terutama bagi anak yang sulit menceritakan masalahnya maka sebaiknya untuk menghadapi anak seperti tipe ini yang membutuhkan waktu yang lama dalam memahami anak tersebut maka sangat ditekankan kepada guru untuk mebina hubungan dengan siswanya dengan sebaik mungkin agar anak tersebut mau bercerita terhadap bimbingan moral yang diberikan dan biasanya mereka akan bisa lebih meyerap pengajaran yang diberikan gurunya. Tanpa hubungan baik pengaruh moral sang guru akan berkurang.

3. Seorang guru harus mampu berperan sebagai pendidik dan dapat mengubah perilaku murid sesuai dengan ajaran baik dan benar

Dalam proses belajar mengajar guru tidak terbatas sebagai penyampai ilmu pengetahuan akan tetapi lebih dari itu, ia bertanggung jawab akan keseluruhan perkembangan kepribadian siswa. ${ }^{32}$

Hasyim Asy'ari mengatakan seorang pendidik seharusnya memperhatikan keadaan para pelajar terutama dalam hal tatakrama, pendidikan dan akhlak yang mana jika para pelajar melakukan perilaku yang tidak terpuji maka pendidik perlu memperbaikinya atau menegurkan di mulai dengan cara yang halus hingga cara-cara yang tegas yakni ada 5 tahapan.

1) Melarang dengan sindiran.

2) Melarang dengan menemuinya secara pribadi.

3) Melarang dengan isyarat di depan rekan-rekannya.

4) Melarang secara tegas di depan rekan-rekannya.

5) Mengusir dan mengabaikan pelajar.

\footnotetext{
${ }^{31}$ Sardiman A.M, Interaksi dan Motivasi Belajar Mengajar, (Jakarta : rajawali pres, 2014), 147.

${ }^{32}$ Slameto, Belajar dan Faktor-faktor Yang Mempengaruhinya ( Jakarta, Rineka Cipta, 2010), 97.
} 


\section{JK'

Sama halnya dengan Thomas Lickona yang menjelaskan bahwa seorang guru harus mengajari siswanya terhadap nilai-nilai moral inti yaitu sikap hormat dan tanggung jawab yang diajarkan melalui 10 cara sebagai berikut.

1) Membangun komunitas moral di dalam kelas.

2) Disiplin moral.

3) Menciptakan lingkungan kelas yang demokratis.

4) Mengajarkan nilai-nilai moral melalui kurikulum.

5) Nurani dalam bekerja.

6) Mendorong refleksi moral.

7) Menaikkan level diskusi moral.

8) Pembelajaran kooperatif.

9) Mengajarkan isu kontroversial.

10) Menagajarkan cara menyelesaikan konflik.

Pada intinya meskipun berbeda pendekatan yang dilakukan Hasyim Asy'ari dan Thomas lickona tentang peran guru sebagai pendidik yang dapat mengubah perilaku siswa melalui ajaran yang baik dan benar, tapi itu mengandung pengertian yang sama. Hasyim Asy'ari mengatakan seorang pendidik harus memperhatikan tatakrama pelajar ini sama artinya dengan pemikiran Lickona bahwa seorang pendidik harus menanamkan nilai-nilai inti kepada siswa.

\section{Perbedaan pemikiran pendidikan karakter menurut Hasyim Asy'ari dan Thomas Lickona}

Dilihat dari pembahasan diatas yang sudah dikaji terdapat perbedaan yang sangat mencolok antara pemikiran Hasyim Asy'ari dan Thomas Lickona, mulai dari latar belakang keluarga,kondisisosial, ekonomi, politik, agama dan pendidikan yang mereka tempuh yang menjadikan pola pikir mereka berbeda mengenai pendidikan karakter. Dan setelah dikaji ada 4 hal yang menjadi perbedaan pemikiran keduanya.

a. Landasan berfikir

Paradigma berpikir yang dibangun Hasyim Asy'ari berbeda dengan Thomas Lickona yang lebih memilih gerakan purifikasi pembaharuan pendidikan karakter yang moderat yang pemikirannya lahir dari gejolak atau konflik masyarakat sehingga pemikiran beliau cenderung kepada solusi yang ditawarkan untuk menanamkan pendidikan karakter sedangkan Hasyim Asy'ri lebih dipengaruhi oleh sikap tradisionalisme dengan sedikit menghargai unsur reformasi (yang tidak mendekondutruksi tradisi Islam). Nampak dalam tulisannya yang dimulai dengan uraian tentang signifikasi ilmu dan pendidikan kemudian keutamaan ilmuwan dan para ulama', ini menunjukkan bahwa ada mata rantai yang menghubungkan dengan pendahulunya, terutama al-Ghazali 
yang memang banyak dijadikan rujukan kaum Tradisionalis khusunya yang berkaitan dengan masalah etika. Paradigma dan Stand Poin ini mempengaruhi pemikiran Hasyim Asy'ari dalam kependidikan, baik dalam karya-karyanya maupun dalam intuisi lembaganya.

b. Sumber ajaran religi

Sangat jelas sekali bahwa sumber yang menjadi landasan berpikir Hasyim Asy'ari adalah Al-Qur'an dan sunnah yang mana agama harus diamalkan secara murni sesuai tuntunan Nabi. Karena itu amalan yang tidak ada dasarnya dalam kitab dan sunnah, harus dicegah agar tak menimbulkan Bid'ah. Hasyim Asy'ari mencita-citakan berlakunya nilai-nilai Islam dalam kehidupan bermasyarakat, berbangsa dan bernegara dengan tujuan agar manusia selalu berusaha untuk mendekatkan diri kepada Allah agar mendapatkan kebahagian dunia dan akhirat. Hal ini berbeda sekali dengan Thomas Lickona, yang sudah dijelaskan di atas bahwa Thomas Lickona adalah penganut agama Katolik, maka sumber ajaran religinya tersebut menganut pada ajaran yang beliau terima, yang salah satu perkatan Thomas Lickona di prakata bukunya bahwa" semua kebenaran berasal dari Roh Kudus" dan ada kalimat di dalam bukunya berbunyi " orang yang malas bekerja adalah orang yang suka merusak (Amsal 18:9). ${ }^{33}$

c. Setting sosial

Seorang Hasyim Asy'ari adalah tokoh salaf bahkan guru besar Islam yang sangat taat, wirai dan berkecimpung di dunia pesantren yang hidup pada masa penjajahan dan turut dalam perjuangan merebut dan mempertahankan kemerdekaan Republik Indonesia yang kala itu presiden pertama Indonesia adalah Soekarno. Hal ini berbeda sekali dengan Thomas lickona yang seorang psikologi Amerika beragama Katolik yang juga taat terhadap agamanya dan sampai saat ini Thomas Lickona masih eksis di dunia pendidikan khususnya pengembangan Wallace periode 1941-1945 samapi saat ini presiden Barrac Obama dan mengapa pula pemikiran mereka berbeda, ini dikarenakan kondisi zaman yang telah berubah ketika kitab Adab al-'Alim wa-al Muta'allim yang berisi tentang pemikiran Hasyim Asy'ari di karang kondisinya berbeda dengan paradigma baru pendidikan saat ini. Yang mana perkembangan dunia pendidikan saat ini bergerak amat cepat. Seluruh komponen pendidikan harus terus menerus di inovasi dan dikembangkan sesuai dengan paradigm baru yang terus berkembang. ${ }^{34}$ disaat Hasyim asy'ari mengarang kitabnya zaman belum seglobal ini, belum banyak pengaruh-pengaruh negatif seperti media massa internet, yang menyebabkan pemikiran Hasyim Asy'ari cenderung ditekankan kepada seorang pendidik dan pelajar saja dan ini sama sekali berbeda dengan

33 Thomas Lickona, Educating for Character 268.

${ }^{34}$ Abudin Nata, Persepektif Islam Tentang Strategi Pembelajaran(Jakarta: Kencana Prenada Media Group, 2009), 25. 


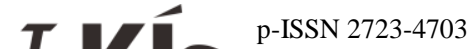

Thomas Lickona ketika menuangkan pemikirannya di bukunya Educating For Character di zaman yang sudah banyak pergaulan bebas dan pengaruh buruk lainnya menyebabkan konsep karakter yang dia tawarkan bukan guru saja melainkan semua pihak yang berhubungan dengan perkembangan moral siswa baik itu pihak sekolah, keluarga dan masyarakat semuanya harus andil untuk menciptakan generasi yang lebih baik karakternya di tengah zaman yang rusak ini.

\section{SIMPULAN DAN SARAN}

Sebagai akhir dari bagian skripsi ini penulis mengemukakan kesimpulan berdasarkan pembahasan sebelumnya mengenai pendidikan karakter dalam pemikiran Hasyim Asy'ari dan Thomas Lickona.

Menurut KH.Hasyim Asy'ari mengenai konsep pendidikan karakter ini beliau lebih condong membahas karakter subyek dan obyek pendidikan yaitu guru dan murid. Hal ini bisa dilihat dari karya beliau kitab Adab al-'Alim wa-al Muta'allimyang membahas tentang :
a. Keutamaan ilmu, 'ulama', dan belajar mengajar
b. Karakter pelajar terhadap diri sendiri :
c. karakter pelajar terhadap pendidik
d. karakter pelajar terhadap pelajaran
e. karakter orang berilmu pada diri sendiri
f. karakter pendidik dalam belajar mengajar
g. karakter pendidik terhadap pelajar
h. karakter terhadap buku pelajaran

Mengenai tentang konsep pendidikan karakter, Thomas Lickona lebih condong tehadap apa yang harus dilakukan guru dan sekolah untuk menanamkan nila-nilai ke dalam jiwa siswa. Hal ini bisa dilihat dari karya beliau yaitu Educating for Character dalam buku ini membahas mengenai hal yang harus dilakukan oleh guru dan sekolah termasuk diantaranya:

a. Strategi mengajarkan sikap hormat dan tanggung jawab di kelas

b. Membangun komunitas moral didalam kelas

c. Menciptakan lingkungan yang demokratis: rapat kelas

d. Mengajarkan nilai-nilai moral melalui kurikulum

e. Pembelajaran kooperatif

f. Nurani dalam bekerja

g. Mendorong refleksi moral

h. Menaikkan level diskusi moral

i. Mengajarkan isu controversial

j. Mengajarkan cara menyelesaikan konflik

k. Peduli sampai keluar kelas 
1. Menciptakan budaya moral positif di sekolah

m. Memberikan pendidikan seks, narkoba dan alkohol

n. Kerja sama sekolah,orang tua dan masyarakat

Setelah dikaji dapat ditarik benang merah mengenai persamaan dan perbedaannya. Persamaan pemikiran diantara dua tokoh tersebut mengenai pemikiran pendidikan karakter yaitu sama-sama menganjurkan peran seorang guru dalam menanamkan pendidikan karakter, sedangkan perbedaanya adalah pada pemikiran Hasyim Asy'ari mengenai pemikiran pendidikan karakter yang ditekankan hanya dua pihak dari komponen pembelajaran yaitu karakter pendidik dan pelajar sedangkan Thomas Lickona dalam konsep pemikirannya menekankan semua pihak yaitu keluarga, sekolah, dan masyarakat turut andil dalam menanamkan pendidikan karakter.

\section{DAFTAR PUSTAKA}

Ahmadi, Abu, Nur Uhbiadi. Ilmu Pendidikan, PT. Rineka Cipta, Jakarta, 2001.

Barnawi, M. Arifin. Strategi dan Kebijakan Pembelajaran Pendidikan Karakter, Ar-Ruuz Media, Jogjakarta, 2012.

Lickona, Thomas. Pendidikan Karakter Panduan Lengkap Mendidik Siswa Menjadi Pintar dan Baik:, (Terj.) Lita S, Nusa Media, Bandung, 2013.

Ma'mur,Jamal Asmani. Buku Panduan Internalisasi Pendidikan Karakter Di Sekolah, Diva Press, Yogyakarta, 2011.

Maisah. Manajemen Pendidikan, Gaung Persada Press, Jakarta, 2013.

Margono, S. Metodologi penelitian pendidikan, PT Rineka Cipta, Jakarta, 2010.

Moeloeng, Lexy J. Metodologi Penelitian Kualitatif, Remaja Rosda Karya, Bandung, 2005.

Muslih, Masnur. Pendidikan Karakter: Menjawab Tantangan Krisis Multidimensional, PT Bumi Aksara, Jakarta, tt.

Muwafik, Akh Sholeh. Membangun Karakter Dengan Hati Nurani, Erlangga, Jakart, 2012.

Asy'ari, Hasyim. Pendidikan Karakter Khas Pesantren (Terj.)Rosidin, GENIUS, Malang, 2014.

Puccy, Larry P dan Narvaes, Narcia. Hand Book Pendidikan Moral dan Karakter, (Terj) Imam Baihaqi dan Derta Sri Widowati, Nusa Media Ujung Berung, Bandung, 2014.

Ramayulis. Ilmu Pendidikan Islam, Kalam Mulia, tkp, 2012.

Samho, Bartolomeus. Visi Misi Pendidikan Ki Hajar Dewantara Tantangan dan Relevansinya, Kanisius Anggota Ikapi, Yogyakarta, 2013.

Suprayoga, Imam. Quo Hadist pendidikan Islam pembacaan Realitas pendidikan Islam, Sosial dan keagamaan, UIN Malang Press, Malang, 2006. 
Suprayogo, Imam. Menghidupkan Jiwa Ilmu, kumpulan Kolom Seputar Pendidikan, PT Elex Media Komputindo, Jakarta,2014.

Wibowo, Agus. Pendidikan Karakter Strategi Membangun Karakter Bangsa dan Peradaban, Pustaka Belajar, Yogyakarta, 2012.

Zaenal, Asep. Islamic Characther Building, PT Grafindo Media Pratama, Jakarta, 2014.

Zubaedi. Desain Pendidikan Karakter Konsepsi dan Aplikasinya dalam Lembaga Pendidikan, Kencana, Jakarta, 2012.

Zuhdi, Damiyati dkk. Model Pendidikan Karakter, Pustaka Pelajar, Yogyakarta, 2013. 